\title{
Anti-HIV activity of ellagitannins from alder tree fruits
}

\author{
T. Yu. Trokhymchuk ${ }^{1}$, A. S. Shalamay ${ }^{2}$, M. P. Zavelevich ${ }^{3}$, L. G. Palchykovska ${ }^{4}$, \\ O. V. Vasylchenko ${ }^{4}$, S. L.Rybalko ${ }^{5}$, D. B. Starosyla ${ }^{5}$, S. T. Diadiun ${ }^{5}$ \\ ${ }^{1}$ Joint-Stock Company "Diaproph-Med" \\ 35, Svetlitsky str., Kyiv, Ukraine, 04123 \\ ${ }^{2}$ Borschagovsky CPP, Kyiv, Ukraine \\ 17, Myru str. 17, Kyiv, Ukraine, 03134 \\ ${ }^{3}$ R. E. Kavetsky Institute of Experimental Pathology, Oncology and Radiobiology, NAS of Ukraine \\ 45, Vasylkivska Str., Kyiv, Ukraine, 03022 \\ ${ }^{4}$ Institute of Molecular Biology and Genetics, NAS of Ukraine \\ 150, Akademika Zabolotnoho Str., Kyiv, Ukraine, 03680 \\ ${ }^{5}$ Gromashevsky L. V. Institute of Epidemiology and Infectious Diseases, NAMS of Ukraine \\ 5, Amosova Str., Kyiv, Ukraine, 03038 \\ mzavelevych@yahoo.com
}

\begin{abstract}
Aim. To assess the inhibitory activity of ellagitannin complex of the purified extract from the fruits of white alder and black alder in non-eukaryotic polymerase systems and to analyze the effects of these substances on the reverse transcriptase of murine leukemia virus and HIV reproduction in vitro. Methods. Chronically infected MT4/BIII culture of human leukemic cells was used as the HIV source. Anti-HIV activity of the ellagitannin-containing extract was estimated by the reduction of HIV infectious titer in the MT- 4 cells. The inhibitory effects of the extract on retroviral reverse transcriptase, T7 RNA-polymerase and Taq polymerase were also studied in cell-free systems. Results. The ellagitannin extract inhibited activities of the reverse transcriptase of murine leukemia retrovirus, T7 RNA-polymerase, and Taq polymerase. It also reduced the HIV infectious titer in MT-4 cells with $\mathrm{IC}_{50}$ of $1.5 \mu \mathrm{g} / \mathrm{ml}$ and selectivity index of 87. Conclusions. The ellagitannin complex possesses a significant anti-HIV activity. Its in vitro antiviral effect is achieved with a relatively low toxicity.
\end{abstract}

Ke y w or d s: ellagitannins, HIV, anti-HIV activity, reverse transcriptase, T7 RNA-polymerase, Taq polymerase.

\section{Introduction}

Natural products of plant origin are widely used as the remedies in the traditional herbal medicine and considered as the sources for various pharmaceutical applications. Different classes of phenolic compounds are extensively studied as the potential antiviral substan-

(C) 2018 T. Yu. Trokhymchuk et al.; Published by the Institute of Molecular Biology and Genetics, NAS of Ukraine on behalf of Biopolymers and Cell. This is an Open Access article distributed under the terms of the Creative Commons Attribution License (http://creativecommons.org/licenses/by/4.0/), which permits unrestricted reuse, distribution, and reproduction in any medium, provided the original work is properly cited 
ces [1]. Gallotannins and ellagitannins as the major groups of hydrolysable tannins represent an important class of polyphenolic compounds. They are widely distributed in many species of plants and identified as the active constituents of the traditional Chinese herbal preparations used for many centuries as anti-inflammatory, hemostatic, and astringent remedies. Ellagitannins are the esters of hexahydroxydiphenic acid and monosaccharide tending to form high molecular weight dimers and oligomers. The chemical structure and the biological activities of isolated individual ellagitannin species have been extensively studied [2]. The potent antioxidant activity of many ellagitannins contributing to their antibacterial properties has been demonstrated [3].

More recently, several more specific activities of ellagitannins have been discovered. The remarkable chemical stability of most ellagitannins proved to be advantageous for evaluating their biological and pharmacological activities. A number of the reports disclosed antiproliferative, proapoptotic, and antiangiogenic activities of these substances [4]. Several studies have been initiated to assess possible antiviral activities of ellagitannins. These substances turned out to inhibit reproduction of the enveloped viruses of various taxonomic groups due to binding different proteins and altering their structure. The monomeric hydrolyzable tannins, oligomeric ellagitannins and condensed tannins possessing galloyl or hexahydroxydiphenoyl groups have been shown to inhibit herpes simplex virus infection $[5,6]$. Several studies demonstrated the activity of hydrolysable tannins against hepatitis $\mathrm{C}$ virus [7].

The natural products as antiviral and in particular anti-HIV agents have been in the focus of numerous studies [8]. A lot of research on the herbal compounds as anti-HIV substances have been performed. The substances from various classes of polyphenolics seem to be promising for supplementing anti-HIV therapy [9]. Nevertheless, the data on anti-HIV activities of hydrolysable tannins, in particular ellagitannins, are scarce. It has been shown that several ellagitannins inhibit HIV-induced cytopathic effects and HIV-specific antigen expression $[10,11]$. However, the mechanisms of antiviral activities of ellagitannins have not yet been elucidated.

A number of virus-specific enzymes related to DNA and RNA synthesis, i.e., transcription, reverse transcription, replication, DNA relaxation, etc. are proved as the effective targets for the therapeutic agents. The vast majority of the antiviral substances have been designed as the inhibitors of virus-specific polymerases since viral enzymes differ from polymerases involved in maintaining the replication in noninfected cells. In fact, ellagitannins and natural products in general seem to target various stages in the replicative cycle of viruses that are under control of specific enzymes of virions or enzymes synthesized on the templates of viral nucleic acids. In particular, in antiretroviral therapy the widely used drugs represent the inhibitors of HIV reverse transcriptase and HIV protease [12]. Kakiuchi et al. demonstrated the inhibitory activity of tannins on reverse transcriptase from RNA tumor virus [13]. These data were confirmed by inhibition of HIV reverse transcriptase with the gallotannin-containing fraction and the isolated ellagitannins geraniin and corilagin [14]. The fact that these substances inhibit reverse transcriptases of the inhibitor-resistant HIV variants is of particular interest taking into account that high HIV vari- 
ability and the development of resistant strains is a serious problem for the chemotherapy of HIV infection. Several ellagitannins demonstrated anti-protease activities in both HIV and hepatitis $\mathrm{C}$ virus infection $[7,15]$.

The assays of putative HIV inhibitors in the systems with various nucleic acid polymerases such as viral DNA polymerases and RNA-dependent RNA polymerases may be crucial as the first stage of antiviral drug screening [16]. The previous studies suggested that the combination of several non-eukaryotic polymerase systems may be useful as the primary screening tool for antiviral substances of different classes of natural and synthetic compounds [17]. Earlier, this system was successfully used in the screening of several herbal flavonoids as the putative antiviral agents [18]. Later on, we confirmed their anti-HIV activity in specific assays [19]. Bearing in mind the recent data on the anti-HIV effects of several ellagitannins $[10,11,13]$, we attempted to use the similar methodological approach in assessing the presumed anti-HIV activities of ellagitannin complex of the purified extract from the fruits of white alder and black alder.

The aim of the present research was to assess the inhibitory activity of ellagitannins in non-eukaryotic polymerase systems for screening and further analyzing the effects of these substances on the activities of the reverse transcriptase of murine leukemia virus and HIV reproduction in vitro.

\section{Materials and Methods}

\section{Viruses}

The stock of the laboratory adapted BIII strain of HIV-1 was obtained from the Depository of
Viruses of D.I. Ivanovskii Institute of Virology (Moscow, Russia). The virus was maintained in chronically infected virus-producing MT4/BIII culture of lymphoblastoid cells. Earlier, the indirect immunofluorescence with anti-p24 monoclonal antibody confirmed that practically all the cells in culture were infected. The viruscontaining culture fluid was stored at $-70^{\circ} \mathrm{C}$.

Virus of murine leukemia (MuLV) was produced by NML cells kindly provided by Dr. Yu. Kudriavets (R.E. Kavetsky Institute of Experimental Pathology, Oncology and Radiobiology, NAS of Ukraine). The concentrated culture medium of NML cells was used as a source of the reverse transcriptase.

In vitro virological assays were performed in the Laboratory of Experimental Chemotherapy of Viral Infections, L.V. Gromashevsky Institute of Epidemiology and Infectious Diseases, NAMS of Ukraine that was certified by SE Ukrmetrteststandard as conforming to the requirements of Good Laboratory Practice for research of antiviral activities of chemical and herbal substances in animals and in cell cultures (PT No. 426/14 of December 8, 2014).

\section{Cell cultures}

MT-4 cell line originated from human T-cell acute leukemia was obtained from the Cell Depository of R.E. Kavetsky Institute of Experimental Pathology, Oncology and Radiobiology of the NAS of Ukraine. The cells were cultured in suspension by conventional techniques in RPMI 1640 medium with $10 \%$ of fetal calf serum (Sigma, USA) supplemented with gentamicin $(40 \mu \mathrm{g} / \mathrm{mL})$. The culture was passaged once in 3-4 days by dilution with fresh medium at an initial cell density of $2.5 \times 10^{5}$ cells $/ \mathrm{ml}$. 
The primary culture of human embryonic cells was obtained by trypsinization of human embryonic tissue (12-14 weeks). The use of human embryonic tissue in the experiments was strictly adhered to the Law of Ukraine "About organ transplantation and other anatomic materials to the person" No. 1007-XIV (Section 19) in version of October 26, 2014 in conformance with the Convention for the Protection of Human Rights and Dignity of the Human Being with regard to the Application of Biology and Medicine: Convention on Human Rights and Biomedicine (ETS No.164).

\section{Ellagitannin-containing extract}

The extract from the fruits of white alder and black alder (Alnus qlutinosa L.Gaern and Alnus incana L. Moench) was obtained and partially purified at the Research-and Scientific Department of "Borshchahivskiy" CPP PJSC (Kyiv, Ukraine). The ellagitannins in dry extract (not less than $58 \%$ ) were represented by the monomeric, dimeric and oligomeric compounds containing hexahydroxydiphenic acid and valoneic acid dilacton with monomeric ellagitannins amounting to $15-20 \%$ of ellagitannin content. The sterile dry extract was diluted in RPMI-1640 medium.

\section{Cytotoxicity assay}

MTT test was used to assess the cytotoxicity of the extract. MT-4 cells were seeded in a 96 -well plate $\left(5 \times 10^{4}\right.$ per well in a volume of $200 \mu \mathrm{l})$ and various concentrations of the extract were added in triplicate. The cells were incubated for 5 days at $37{ }^{\circ} \mathrm{C}$ in a $5 \% \mathrm{CO}_{2^{-}}$ humidified incubator. Then MTT $(5 \mathrm{mg} / \mathrm{mL}$ in PBS) was added to each well. After incubating for 4 hours, the plates were centrifuged at
1,500 rpm, the supernatant was removed and the dimethyl sulfoxide was added. The plate was incubated for $10 \mathrm{~min}$ at $37^{\circ} \mathrm{C}$ and read on a Bio-Tek Elx 800 ELISA reader at $570 \mathrm{~nm}$. $50 \%$ cytotoxic concentration $\left(\mathrm{CC}_{50}\right)$ was then calculated.

\section{Assay for HIV infectious titer and p24 detection}

The fresh MT4 cells in 96-well plates were infected in three replicates with 10-fold dilutions of HIV-1 produced by MT4/BIII cells. The plates were incubated for 5 days at $37{ }^{\circ} \mathrm{C}$ in $5 \% \mathrm{CO}_{2}$-humidified incubator. The content of p24 HIV was assayed in each well for calculating $50 \%$ end point dilution of virus. p24 expression in culture medium was detected by EIA with DIA-HIV-Ag/Ab test-system (DIA, Ukraine). The neutralization reaction was applied to confirm the presence of p24 HIV in the samples. The diagnostic set Genetic Systems $^{\text {TM }}$ HIV-1 Confirmatory Assay used for this aim comprised the human serum containing antibodies against p24 as HIV-1 Antigen Confirmatory Reagent. The neutralization index was calculated according to the manufacturer's instructions.

\section{Antiviral activity of ellagitannin- containing extract}

Anti-HIV activity of the extract was estimated by the reduction of HIV infectious titer in MT-4 cells. The cells in 96-well plates were treated with serial dilutions of the reconstituted extract in triplicate and infected with HIV (100 ID $_{50}$ per well). The plates were incubated for 5 days at $37{ }^{\circ} \mathrm{C}$ in $5 \% \mathrm{CO}_{2}$-humidified incubator. The supernatants were harvested from each well and titrated for infectious virus 
in fresh MT-4 cells. The inhibitory effects on HIV-1 replication in acute infection were assessed by quantification of p24 by ELISA as previously described and expressed as $\mathrm{IC}_{50}$ (inhibitory concentration decreasing HIV infectious titer in half). To assess the specific antiviral activity, $\mathrm{CC}_{50} / \mathrm{IC}_{50}$ ratio was calculated and presented as the selectivity index.

\section{Reverse transcriptase assay}

Supernatants of MuLV-produced NML cells were harvested and assayed for RNA-dependent DNA polymerase activity in 100 -fold concentrates of virus obtained by centrifugation at $100,000 \mathrm{~g}$ for $1 \mathrm{~h}$. The reaction mixture $(100 \mu \mathrm{l})$ contained $50 \mathrm{mM}$ Tris-HCI, $\mathrm{pH}$ 7.8; $60 \mathrm{mM}$ potassium chloride; $2 \mathrm{mM}$ dithiotreitol; $0.25 \mathrm{mM} \mathrm{MnCl}_{2} ; 0.1 \%$ (v/v) Triton X-100; $0.02 \mathrm{AU} / \mathrm{ml}$ poly rA-oligo $\mathrm{dT}_{12}$ and $20 \mu \mathrm{M}$ ${ }^{3} \mathrm{H}$-TTP, specific activity $2.37 \mathrm{TBq} / \mathrm{mmol}$ (Amersham, Great Britain). The samples were incubated at $37^{\circ} \mathrm{C}$ for $60 \mathrm{~min}$. Trichloroacetic acid-insoluble radioactivity was measured in Intertechnique SL30 counter (France).

\section{In vitro transcription assay}

The reaction mixture $(20 \mu \mathrm{l})$ of transcription assay contained the linearized DNA template pTZ19R* $(0.5 \mathrm{mg}$ of pTZ19R plasmid with a $341 \mathrm{bp}$ insert cloned in the Ecl136II site), ribonucleoside triphosphates ( $2 \mathrm{mM}$ of each), ribonuclease inhibitor RiboLockTM (10 U), T7 RNA polymerase (12 U) (Fermentas, Lithuania), Tris-HCl (40 mM, pH 7.9), $\mathrm{MgCl}_{2}$ $(6 \mathrm{mM})$, spermidine $(2 \mathrm{mM}), \mathrm{NaCl}(10 \mathrm{mM})$ and dithiothreitol $(10 \mathrm{mM})$. The sterile dry ellagitannin-containing extract diluted in DMSO $(1 \mathrm{mg} / \mathrm{ml})$ was added to the reaction mixture and the mixture was incubated for
$45 \mathrm{~min}$ at $37^{\circ} \mathrm{C}$. The final concentration of DMSO in reaction mixture was below $1 \%$. Then the reaction was stopped by cooling up to $-20^{\circ} \mathrm{C}$, and the products were separated by gel electrophoresis in $1 \%$ agarose in TBE buffer supplemented with ethidium bromide $(0.5 \mathrm{mg} / \mathrm{ml})$ followed by visualization under a standard UV-transilluminator. For calculations, the intensity of electrophoretic bands was measured by densitometry using Scion Image software for Windows and $\mathrm{IC}_{50}$ values for inhibition of RNAP T7 activity were estimated.

\section{PCR-based replication assay}

For a standard PCR, the reagent kit provided by (Thermo Fisher Scientific, Lithuania) was used. The linearized pTZ19R* was used as a template ( $5 \mathrm{ng}$ in $20 \mu \mathrm{l}$ of incubation mixture) with the designed and synthesized specific forward and the reverse primers $(1.1 \mathrm{pmol}$ of each in $20 \mu \mathrm{l}$ of reaction mixture). PCR products were separated by electrophoresis in $1 \%$ agarose and visualized as above.

\section{Mitotic index and cytogenetic analysis}

The effects of ellagitannin-containing extract on mitotic activity and chromosomes were studied in primary cultures of human embryonic tissue. The cells were cultured onto the cover slips, fixed in ethanolic copper nitrate formalin and stained with hematoxylin - eosin. The mitotic index was assessed in 3000 cells and expressed in parts per thousand (\%o). In the same cell specimens, the percent of pathologic mitoses was estimated. The cytogenetic analysis was performed in metaphase plates of cells exposed to $0.75 \mathrm{mg} / \mathrm{mL}$ of colchicine and processed by standard technique: treatment with $1 \%$ sodium citrate, fixation in 
methanol - glacial acetic acid, staining with azur-eosin.

\section{Results and Discussion}

As the first step in the analysis of ellagitannin extract as the potential antiviral substance, its effects were studied in two screening systems containing the enzymes, which are extraneous to eukaryotic cells, namely DNA-dependent RNA polymerase of T7 bacteriophage and Taq DNA polymerase. When assayed in the transcriptional complex of T7 phage RNA polymerase, ellagitannin extract demonstrated an effective inhibition of RNA synthesis with $\mathrm{IC}_{50}$ value of $0.4 \mu \mathrm{g} / \mathrm{ml}$ (Fig. 1). The ellagitannin extract was even more active $\left(\mathrm{IC}_{50}\right.$ of $0.15 \mu \mathrm{g} /$ $\mathrm{ml})$ in the system of DNA synthesis in the set-

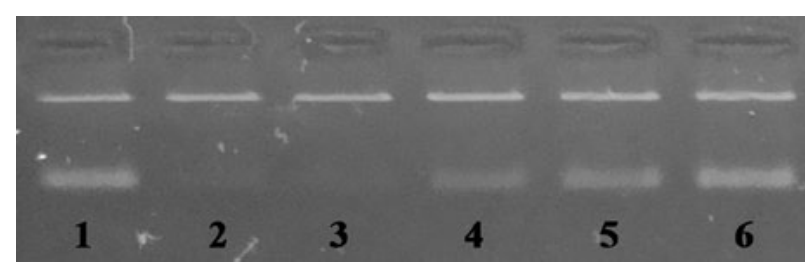

Fig. 1. Inhibition of RNA synthesis in vitro in T7 RNA polymerase system. The absence of the visualized band corresponding to reaction product in agarose gel means the complete inhibition. 1 - control; 2-6 - ellagitannin: $2-12.8 \mu \mathrm{g} / \mathrm{ml} ; 3-3.2 \mu \mathrm{g} / \mathrm{ml} ; 4-0.8 \mu \mathrm{g} / \mathrm{ml}, 5-$ $0.2 \mu \mathrm{g} / \mathrm{ml} ; 6-0.05 \mu \mathrm{g} / \mathrm{ml}$.

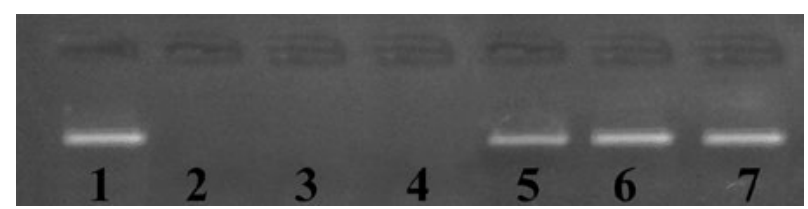

Fig. 2. Inhibition of DNA synthesis in vitro in Taq polymerase system. The absence of the visualized band corresponding to reaction product in agarose gel means the complete inhibition. 1 - control; 2-7 - ellagitannin: $2-12.8 \mu \mathrm{g} / \mathrm{ml} ; 3-3.2 \mu \mathrm{g} / \mathrm{ml} ; 4-0.4 \mu \mathrm{g} / \mathrm{ml} ; 5-$ $0.1 \mu \mathrm{g} / \mathrm{ml} ; 6-0.05 \mu \mathrm{g} / \mathrm{ml} ; 7-0.012 \mu \mathrm{g} / \mathrm{ml}$ ting of PCR (Fig. 2). Therefore, both RNA synthesis catalyzed by T7 RNA polymerase and synthesis of DNA fragments by Taq polymerase were sensitive to the inhibition by ellagitannin extract in concentration-dependent mode. The inhibitory concentrations in cellfree system were of the same order of magnitude as those found for several flavonoid substances assayed in our previous work [18] that provided good reason for assessing ellagitannins under study as antiviral substances in the specific system of HIV-producing cells.

The routine procedures for the assessment of specific antiviral activity require evaluation of the toxicity indices $\left(\mathrm{CC}_{50}\right)$ in the cells being assayed and the concentrations effective for antiviral activity $\left(\mathrm{IC}_{50}\right)$. The cytotoxicity of ellagitannin extract was assessed in MTT assay in MT-4 cells. The dilutions of the extract were added for $1 \mathrm{~h}$ to the wells of microplates with suspension of cells (each dilution was assayed in three replicates). Then the medium was removed and fresh medium was added for $72 \mathrm{~h}$. The results of the cytotoxicity assay (Fig. 3) show that $\mathrm{CC}_{50}$ of ellagitannin extract for MT-4 cells is $87 \mu \mathrm{g} / \mathrm{ml}$.

Then the anti-HIV activity of ellagitannin extract was assayed in the model of productive infection of HIV in MT-4 cells. For this purpose, MT4/BIII cells continuously producing HIV-1 were used. For characterizing the parameters of HIV productive infection in MT4/ BIII cells we first confirmed the identity of HIV produced by MT4/BIII cells with HIV-1 by neutralization with human anti-p24 HIV-1 antiserum. The neutralization index for HIV in MT-4 cells was calculated as $98.4 \%$. To prove the infectivity of the virus produced by MT4/BIII cells for MT-4 cells and to assess 


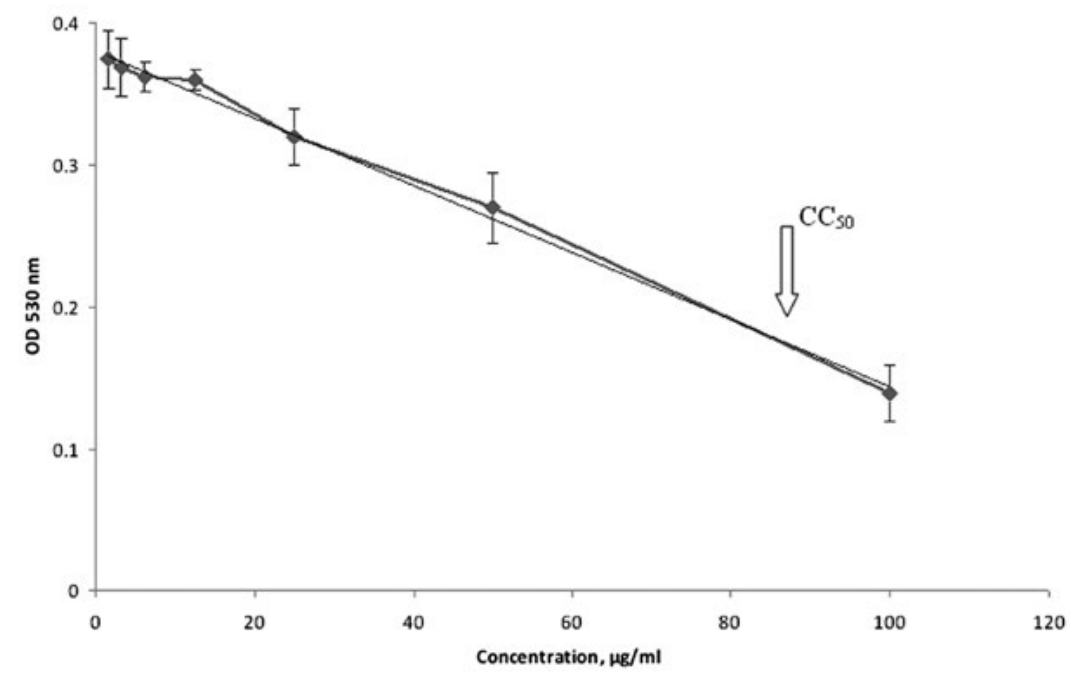

Fig. 3. Cytotoxicity of ellagitannin extract in MT-4 cells. Cells were incubated with serial dilutions of the extract for 5 days. Percent of viable cells was assayed in MTT test. $\mathrm{CC}_{50}$ was calculated by linear regression. $\mathrm{CC}_{50}$ value is marked with arrow.

HIV infectious titer in MT-4 cells we have infected fresh MT-4 cell suspensions with 10 -fold serial dilutions of HIV produced in MT4/BIII cells (each dilution of virus was assayed in triplicate).

HIV infectious titer in MT-4 cells was estimated by detection of infectivity for MT-4 cells in 10-fold serial dilutions of HIV produced in MT4/BIII cells (each dilution of virus was assayed in triplicate). The $50 \%$ end-point dilution was measured by p24 assay. The infectious HIV titer in MT4 cells calculated by Reed-Muench equaled $4.6 \operatorname{lgID}_{50}$ (Fig. 4).

The Anti-HIV activity of the extract was estimated by the reduction of the HIV infectious titer in MT-4 cells. The serial dilutions of the extract within the range of $0.5-40 \mu \mathrm{g} / \mathrm{ml}$ were prepared and applied to each well with MT-4 cells simultaneously with $100 \mathrm{ID}_{50}$ of HIV (each dilution of the extract in triplicate). After 5-day incubation, HIV titer in each well was assayed by titration of the culture medium in fresh MT4 cells as indicated above. As shown in Fig. 5, the ellagitannin extract exhibited the anti-HIV activity inhibiting the infectious titer of virus in MT-4 cells. $\mathrm{IC}_{50}$ calculated by linear regression was $1.5 \mu \mathrm{g} / \mathrm{ml}$ and $\mathrm{IC}_{90}-5.0 \mu \mathrm{g} / \mathrm{ml}$. Therefore, the ellagitannin extract effectively inhibits HIV

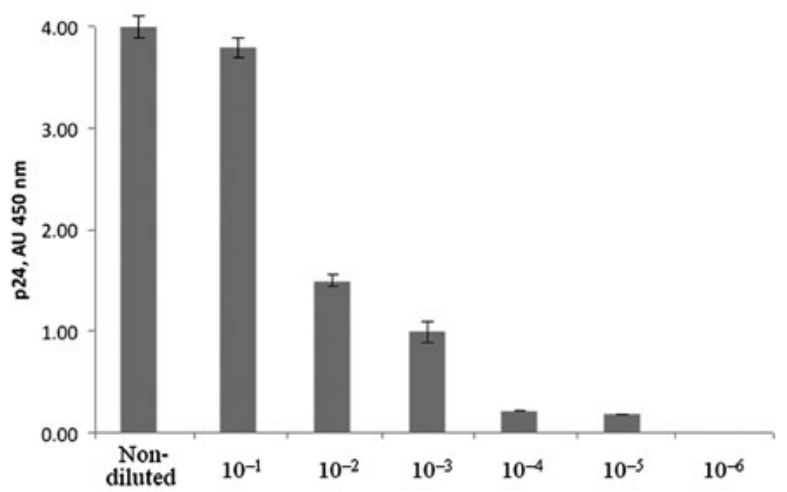

Fig. 4. Titration of HIV in MT-4 cells. The cells were infected with 10-fold dilutions of HIV-1 in three replicates and the plates were incubated for 5 days at $37^{\circ} \mathrm{C}$. The supernatants from the cells infected in each dilution were then harvested and titrated for infectious virus in fresh MT-4 cells. p24 in culture medium was detected by EIA using DIA-HIV-Ag/Ab test-system. 
reproduction causing the reduction of HIV infectivity by $1 \log \mathrm{ID}_{50}$ in the concentration of $5 \mu \mathrm{g} / \mathrm{ml}$ producing quite favorable $\mathrm{CC}_{50}$ to $\mathrm{IC}_{50}$ and $\mathrm{CC}_{50}$ to $\mathrm{IC}_{90}$ ratios.

Tannins, and in particular ellagitannins are multi-target substances and it is difficult to delineate the principal effects contributing to their antiviral activity. Nevertheless, most synthetic and natural HIV inhibitors are known to mediate their activity via inhibition of viral enzymes. Therefore, we have attempted to measure the putative inhibitory activities of ellagitannin extract in cell-free system. RT is one of the key targets of many synthetic HIV inhibitors designed as retroviral drugs [20]. We analyzed the effect of the extract on MuLV reverse transcriptase that shares many similarities in

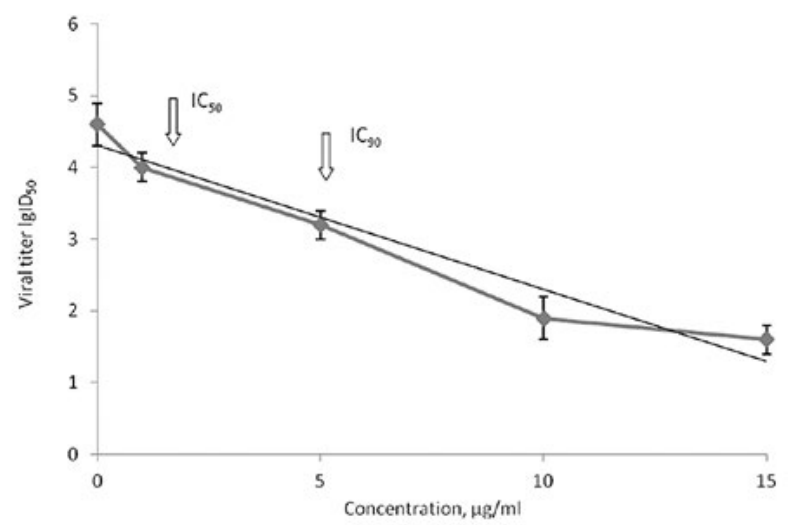

Fig. 5. $\mathrm{IC}_{50}$ and $\mathrm{IC}_{90}$ for inhibition of HIV infectivity in MT-4 cells by ellagitannin extract. The serial dilutions of the extract were applied to each well with MT-4 cells simultaneously with $100 \mathrm{ID}_{50}$ of HIV (each dilution of the extract in triplicate). The cells with virus and dilutions of the extract as well as controls were incubated for 5 days at $37^{\circ} \mathrm{C}$. Upon the incubation, HIV titer in each well was assayed by titration of the culture medium in fresh MT4 cells. The decrease in HIV infectious titer was assessed. $\mathrm{IC}_{50}$ (decline of virus titer in half) and $\mathrm{IC}_{90}$ (tenfold decline of virus titer) were calculated by linear regression. $\mathrm{IC}_{50}$ and $\mathrm{IC}_{90}$ values are marked with arrows. its enzymatic and molecular characteristics with HIV reverse transcriptase although some subtle differences do exist [21]. Fig. 6 demonstrates that an addition of the extract to the complete incubation mixture in concentrations within $20-200 \mu \mathrm{g} / \mathrm{mL}$ resulted in the significant inhibition of ${ }^{3} \mathrm{H}-\mathrm{TTP}$ incorporation into poly rA - oligo dT used as exogenous template for MuLV reverse transcriptase. At $20 \mu \mathrm{g} / \mathrm{mL}$, the inhibiting effect amounted to $60 \%$.

Further evidence for the safety of the composition under study was provided by analyzing mitotic parameters and chromosomal aberrations in the cells of primary cultures of human embryonic tissue cultured in the presence of ellagitannins in concentration of $20 \mu \mathrm{g} / \mathrm{ml}$. The results are presented in Table.

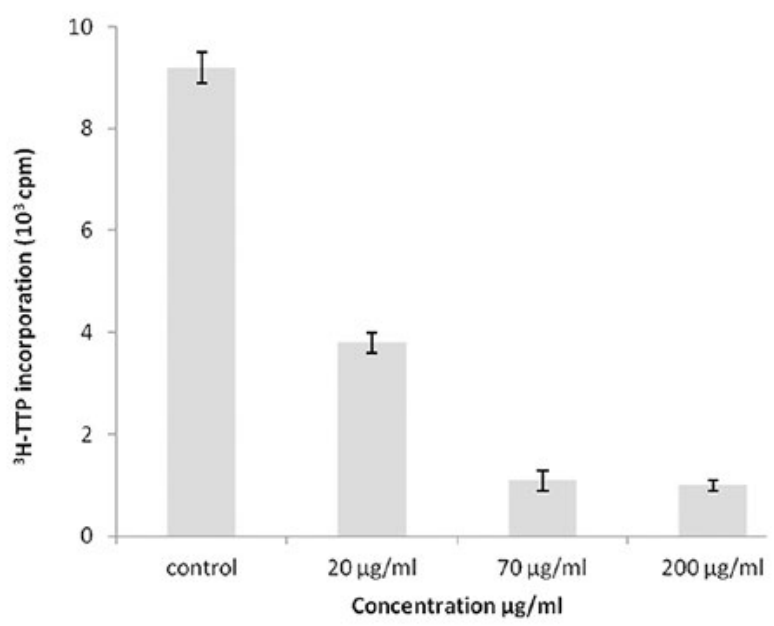

Fig. 6. Effect of ellagitannin extract on reverse transcriptase activity of murine leukemia virus. The extract redissolved in polyethylene oxide 400 was added to the incubation system for assaying the activity of reverse transcriptase with poly rA - oligo dT used as exogenous template. The reaction was terminated in 1 hour and trichloroacetic acid-insoluble radioactivity in the samples with or without extract was measured as the amount of ${ }^{3} \mathrm{H}$-TTP incorporation. 
Table. Mitotic parameters and chromosomal aberrations in the cells of primary cultures of human embryonic tissue cultured with ellagitannin extract

$\mid \begin{aligned} & \text { Cells } \\ & \text { Non-treated } \\ & \text { Treated with ellagitannin extract }\end{aligned}$

Therefore, ellagitannins in concentrations well above $\mathrm{IC}_{50}$ for HIV reproduction did not affect the mitotic parameters. The count of chromosomal aberrations was not significantly higher than in control cultures. Moreover, only gaps were detected as the dominant form of chromosomal aberrations. These parameters of safety are in line with the data on cytotoxicity of the assayed extract.

The screening system used in our study seemed to be helpful in selecting potential antivirals without the need of specific HIV assays at the first step. Actually, the preliminary screening of the ellagitannin complex of the purified extract from the fruits of white alder and black alder turned out to be promising for the subsequent specific anti-HIV assays that finally confirmed the significant anti-HIV activity in the productive system of HIVinfected MT-4 cells.

The relative effectiveness and specificity of any investigational drug in inhibiting viral replication as compared to inducing cell death is defined as the therapeutic or selectivity index (SI). With $\mathrm{IC}_{50}$ of $1.5 \mu \mathrm{g} / \mathrm{ml}$ and $\mathrm{CC}_{50}$ of $87 \mu \mathrm{g} / \mathrm{ml}$, SI of ellagitannins under study in our system of HIV-producing MT-4 cells amounts to 57. According to the currently accepted methodical guides for the development of the antivirals, the substances with SI above 4 are considered as positive whereas the substances with SI above 8 may be considered as the promising candidate substances and recom- mended for the next step of in vivo experimental studies [22, 23]

Our results are in agreement with those presented elsewhere for the substances of this class as antiviral agents. In particular, Cheng et al. demonstrated anti-HSV-2 activity of casuarinin in vitro with $\mathrm{IC}_{50}$ of $1.5 \mu \mathrm{g} / \mathrm{ml}$ [24]. Recently, Bedoya et al. demonstrated anti-HIV activity of ellagitannins with $\mathrm{IC}_{50}$ of $2.3 \mu \mathrm{g} /$ $\mathrm{ml}$ and SI of 20 [25].

\section{Conclusions}

The ellagitannin complex of the purified extract from the fruits of white alder and black alder possesses significant anti-HIV activity inhibiting effectively the HIV reproduction in vitro in human MT-4 cells with $\mathrm{IC}_{50}$ of $1.5 \mu \mathrm{g} / \mathrm{ml}$ and $\mathrm{IC}_{90}$ of $5.0 \mu \mathrm{g} / \mathrm{ml}$. In the experimental setting, the ellagitannin extract inhibits the activities of reverse transcriptase of murine leukemia virus, T7 RNA-polymerase, and Taq polymerase. The advantageous antiviral effects are achieved with low toxicity providing for acceptable values of a selectivity index. The further analysis of possible interactions between the various components of this herbal extract would be beneficial for designing the novel drugs to reduce or block the HIV reproduction.

\section{REFERENCES}

1. Newman DJ, Cragg GM. Natural products as sources of new drugs over the 30 years from 1981 to 2010. J Nat Prod. 2012;75(3):311-35. 
2. Okuda T, Yoshida T, Hatano T. Ellagitannins as active constituents of medicinal plants. Planta Med. 1989;55(2):117-22.

3. Ito $H$. Metabolites of the ellagitannin geraniin and their antioxidant activities. Planta Med. 2011;77(11): 1110-5.

4. Ismail T, Calcabrini C, Diaz AR, Fimognari C, Turrini E, Catanzaro E, Akhtar $S$, Sestili P. Ellagitannins in cancer chemoprevention and therapy. Toxins (Basel). 2016;8(5). pii: E151.

5. Takechi M, Tanaka Y, Takehara M, Nonaka G-I, Nishioka I. Structure and antiherpetic activity among the tannins. Phytochemistry. 1985; 24(10): 2245-50.

6. Fukuchi K, Sakagami H, Okuda T, Hatano T, Tanuma $S$, Kitajima K, Inoue $Y$, Inoue S, Ichikawa $S$, Nonoyama M, Konno K. Inhibition of herpes simplex virus infection by tannins and related compounds. Antiviral Res. 1989;11(5-6):285-97.

7. Ajala OS, Jukov A, Ma CM. Hepatitis C virus inhibitory hydrolysable tannins from the fruits of Terminalia chebula. Fitoterapia. 2014;99:117-23.

8. Kurapati KR, Atluri VS, Samikkannu T, Garcia G, Nair MP. Natural products as anti-HIV agents and role in HIV-associated neurocognitive disorders (HAND): A Brief Overview. Front Microbiol. 2016;6:1444.

9. Orhan DD, Ozçelik B, Ozgen S, Ergun F. Antibacterial, antifungal, and antiviral activities of some flavonoids. Microbiol Res. 2010;165(6):496-504.

10. Nakashima H, Murakami T, Yamamoto N, Sakagami H, Tanuma S, Hatano T, Yoshida T, Okuda T. Inhibition of human immunodeficiency viral replication by tannins and related compounds. Antiviral Res. 1992;18(1):91-103.

11. Dwevedi A, Dwivedi R, Sharma YK. Exploration of Phytochemicals Found in Terminalia sp. and their Antiretroviral Activities. Pharmacogn Rev. 2016;10(20):73-83.

12. De Clercq E. Anti-HIV drugs: 25 compounds approved within 25 years after the discovery of HIV. Int J Antimicrob Agents. 2009;33(4):307-20.

13. Kakiuchi N, Hattori $M$, Namba T, Nishizawa $M$, Yamagishi T, Okuda T. Inhibitory effect of tannins on reverse transcriptase from RNA tumor virus. $J$ Nat Prod. 1985;48(4):614-21.
14. Notka F, Meier G, Wagner R. Concerted inhibitory activities of Phyllanthus amarus on HIV replication in vitro and ex vivo. Antiviral Res. 2004;64(2):93-102.

15. Xu HX, Wan M, Dong H, But PP, Foo LY. Inhibitory activity of flavonoids and tannins against HIV1 protease. Biol Pharm Bull. 2000;23(9):1072-6.

16. Hotta K, Zhu CB, Phomsuwansiri P, Ishikawa J, Mizuno S, Hatsu M, Imai S. PCR inhibition assay for DNA-targeted antibiotics. $J$ Antibiot (Tokyo). 1995;48(11):1267-72.

17. Palchykovska LG, Aleksieieva IV, Shved AD, Rybalko SL. Method for detection of low-molecular inhibitors of biosynthesis of nucleic acids. Patent for utility model of Ukraine N53193 of 27.09.2010.

18. Palchykovska LG, Vasylchenko OV, Platonov MO, Starosyla DB, Porva JI, Rymar SJ, Atamaniuk VP, Samijlenko SP, Rybalko SL. Antiviral properties of herbal flavonoids - inhibitors of the DNA and RNA synthesis. Biopolym Cell. 2013; 29(2): 150-6.

19. Trokhymchuk T, Zavelevich M, Liulchuk M, Starosyla D, Rybalko $S$, Rudenko $A$. In vitro study of anti-HIV activity of proteflazid herbal composition. Am J Fundam Appl \& Exp Res. 2017; 7(4): 87-91.

20. Spedding G, Ratty A, Middleton E Jr. Inhibition of reverse transcriptases by flavonoids. Antiviral Res. 1989;12(2):99-110.

21. Skasko M, Weiss KK, Reynolds HM, Jamburuthugoda V, Lee K, Kim B. Mechanistic differences in RNAdependent DNA polymerization and fidelity between murine leukemia virus and HIV-1 reverse transcriptases. J Biol Chem. 2005;280(13):12190-200.

22. Recurrent Herpes Labialis: Developing Drugs for Treatment and Prevention. Guidance for Industry. U.S. Department of Health and Human Services. Food and Drug Administration. Center for Drug Evaluation and Research (CDER). 2017, 19 p.

23. Preclinical studies of efficacy of chemotherapeutic medicinal products. Ch. 4. Guide on Experimental (Preclinical) Study of Novel Pharmacological Substances. Ed. Khabriev R. M: Meditsina 2005: 501-682.

24. Cheng HY, Lin CC, Lin TC. Antiherpes simplex virus type 2 activity of casuarinin from the bark of Terminalia arjuna Linn. Antiviral Res. 2002;55(3): 447-55. 
T. Yu. Trokhymchuk, A. S. Shalamay, M. P. Zavelevich et al.

25. Bedoya LM, Abad MJ, Sánchez-Palomino S, Alcami J, Bermejo P. Ellagitannins from Tuberaria lignosa as entry inhibitors of HIV. Phytomedicine. 2010;17(1):69-74

\section{Анти-ВІЛ активність елаготанінів із суплідь вільхи}

Т. Ю. Трохимчук, А. С. Шаламай, М. П. Завелевич, Л. Г. Пальчиковська, О. В. Васильченко, С. Л. Рибалко, Д. Б. Старосила, С. Т. Дядюн

Мета. Оцінити інгібувальну активність комплексу елаготанінів в очищеному екстракті плодів вільхи сірої і вільхи клейкої у відношенні полімераз, що не є полімеразами еукаріот, з метою скринінгу та проаналізувати вплив досліджуваних речовин на зворотну транскриптазу вірусу мишачої лейкемії та на репродукцію ВІЛ in vitro. Методи. Джерелом ВІЛ була хронічно інфікована культура клітин лейкемії людини МТ4/ВІІІ. Анти-ВІЛ активність комплексу елаготанінів визначали за зниженням інфекційного титру ВІЛ після зараження вірусом клітин МТ-4. Визначали інгібуючий ефект елаготанінів на активність ретровірусної зворотної транскриптази, РНК-полімерази фага Т7 і Таq-полімерази в безклітинних системах Результати. Досліджуваний екстракт елаготанінів виявився ефективним інгібітором активності зворотної транскриптази вірусу мишачої лейкемії, РНК-полімерази фага Т7 і Таq-полімерази. Комплекс елаготанінів ефективно знижував інфекційний титр ВІЛ для клітин МТ-4. $\mathrm{IC}_{50}$ становила 1,5 мкг/мл, а індекс селективності дорівнював 87. Висновки. Досліджуваний комплекс елаготанінів виявляє виражену анти-ВІЛ активність. Противірусний ефект in vitro досягався при відносно низькій токсичності.

Кл ю ч о в і с л о в а: елаготаніни, ВІЛ, анти-ВІЛ активність, зворотна транскриптаза, РНК-полімераза фага T7, Таq-полімераза

\section{Анти-ВИЧ активность эллаготанинов из соплодий ольхи}

Т. Ю. Трохимчук, А. С. Шаламай, М. П. Завелевич, Л.И. Пальчиковская, А. В. Васильченко, С. Л. Рыбалко, Д. Б. Старосила, С. Т. Дядюн

Цель. Изучить ингибирующую активность комплекса эллаготаннинов в очищенном экстракте соплодий ольхи серой и ольхи клейкой в отношении полимераз, не являющихся полимеразами эукариот, и проанализировать влияние этих веществ на активность обратной транскриптазы вируса мышиного лейкоза и на репродукцию ВИЧ in vitro. Методы. Источником ВИЧ служила хронически инфицированная культура клеток лейкоза человека МТ4/ВІІІ. Анти-ВИЧ активность комплекса эллаготаннинов определяли по снижению инфекционного титра ВИЧ после заражения вирусом клеток МТ-4. Определяли ингибирующий эффект эллаготаннинов на активность ретровирусной обратной транскриптазы, РНК-полимеразы фага Т7 и Таqполимеразы. Результаты. Исследуемые эллаготаннины оказались эффективными ингибиторами активности обратной транскриптазы вируса мышиного лейкоза, РНК-полимеразы фага Т7 и Таq-полимеразы. Исследуемый комплекс эллаготаннинов эффективно снижал инфекционный титр ВИЧ для клеток МТ-4. $\mathrm{IC}_{50}$ составляла 1,5 мкг/мл при индексе селективности 87. Выводы. Изученный комплекс эллаготаннинов обладал выраженной анти-ВИЧ активностью. Противовирусный эффект in vitro достигался при относительно низкой токсичности.

К л юч е в ы е с л о в а: эллаготаннины, ВИЧ, анти-ВИЧ активность, обратная транскриптаза, РНКполимераза фага T7, Таq-полимераза

Received 30.12.2017 